\title{
CURRENT ACCOUNT DEFICIT, BUDGET DEFICIT AND SAVINGS GAP: IS THE TWIN OR TRIPLET DEFICIT HYPOTHESIS VALID IN G7 COUNTRIES?
}

\section{Yusuf Ekrem Akbaş, Fuat Lebe*}

\begin{abstract}
:
The purpose of this study is to determine the validity of the triplet deficit hypothesis, which means the savings gap and budget deficit effect on the current account deficit. The empirical model is estimated for the G7 countries during the period between 1994 and 2011. The findings show that budget deficit and savings gap have important role in current account deficit in terms of estimator results. Moreover, bi-directional causality between the current account deficit and the savings gap and between the budget deficit and the savings gap are determined. So, especially the savings gap has an important effect on the current account deficit and the budget deficit. That is, triplet deficit hypothesis is valid in G7. Moreover, traditional approach is also valid since the causality is found between the current account deficit and budget deficit. Thereby, the authors conclude that the choice of statistical tools in analysing the nature of relationship among the current account deficit, the budget deficit, and the savings gap may play a key role for policy makers.
\end{abstract}

Keywords: current account deficit, budget deficit, savings gap, triplet deficit hypothesis, panel dynamic SUR

JEL Classification: F32, H62, O16, F41, C33

\section{Introduction}

Recently, intensive studies have been conducted on the problems of current account deficits and budget deficits, which emerged in developed countries in the 1980s, when globalization movements started to gain speed in the world economy and gradually spread to emerging countries. It is possible to group the conducted studies around two approaches. The first of these is the traditional (Keynesian) approach (TA), which states that there is a positive relationship between the budget deficit and the current account deficit of a given country and that the direction of this relationship is from budget deficit to current account deficit.

According to this approach, in an economy where a flexible exchange rate is adopted, there will be a decrease in the country's aggregate savings in the event that the taxes collected are smaller than public expenditures. Such a situation will cause the country's national interest rates first to increase and then exceed the global average interest rate. The increase in the national interest rate will lead to an inflow of high amounts of foreign capital into the country and cause an increase in the value of the domestic currency. For this reason, exports will become more expensive, and imports will become cheaper. As a result, net exports will decrease, and the country will experience a current account deficit (Froyen, 1999). Economists who hold the traditional view explain this relationship as the 'twin deficit hypothesis'.

* Yusuf Ekrem Akbaş, Department of Economics, Adıyaman University, Adıyaman, Turkey (akbasyea@gmail.com, akbasyusuf@yahoo.com);

Fuat Lebe, Department of Economics, Adıyaman University, Adiyaman, Turkey (flebe@adiyaman.edu.tr). 
The second approach is the Ricardian equivalence hypothesis (REH), which argues that there is no interaction between the current account deficit and the budget deficit of a given country. The REH states that, while public expenditures are constant, the financing of budget deficits that may result from a decrease in taxes through borrowing will not have any effect on private sector expenditures. In this case, only the timing of tax collection has been shifted from the current period to future periods (Vamvoukas, 1999). Since individuals know that a decrease in the tax revenues of the state will be compensated by future loans or increases in taxes, they know that current liabilities will be repaid through future tax increases (even though the state prefers loans). Therefore, the budget deficits that occur because of public borrowing or tax reductions will not have an increasing effect on private consumption behaviour (assuming that public expenditures do not change). Considering that total domestic savings are composed of the sum of private sector and public sector savings, a decreasing of taxes by the state will also decrease public sector savings, but will increase private sector savings (Barro, 1989). In parallel to the decrease in public sector savings, the increase in the savings of individuals will equal the budget deficit financed by the state. As a result of the increase in private savings, there will be no need for a foreign capital inflow into the country, and a current accounts deficit will not occur (Khalid and Guan, 1999). For this reason, the REH, which was first stated by D. Ricardo and developed by R. Barro, asserts that there is no relationship between the budget deficit and the current account deficit of a given country.

Knowing whether the twin or the triple deficit hypothesis is valid for a country is critically important for policy selection. If policy makers know which hypothesis is valid for the economy of a given country, they can make better decisions in dealing with a budget deficit and current account deficit. The results of studies testing which of the aforementioned hypotheses is valid are therefore important in making decisions. For these reasons, it is important to know whether the triplet deficit hypothesis (TDH) is valid, and if so, how and to what extent it occurs in G7 countries, particularly the US, where deficits have reached significant levels.

A significant part of the commercial and financial transactions around the world are performed by G7 countries. Therefore, it has become inevitable that the developments that occur in these countries spread to developing countries in a globalizing world. The economic policies implemented by developed countries like the USA and the EU are also followed by developing countries and the policies to be adopted are determined according to the policies of developed countries. The global economic crisis that began in 2008 and spread around the world can be given as an example for these developments. In the beginning of the economic crisis, the US economy was the first to feel the negative impact of the crisis. Afterwards, the crisis spread to groups of developed countries like the EU. Eventually, the countries that had intensive economic relations with developed countries were negatively affected by the economic crisis. The USA had applied quantitative easing in order to pull the economy out of recession. Later, the USA used the expansionary fiscal policy. During the global economic crisis, the policy authorities of developing countries also determined their policies based on the policies implemented by the USA and the EU. The shocks that occurred in developed countries and the policies implemented by developed countries are of great importance for developing countries. Therefore, in the present study it is considered that the analysis of $\mathrm{G} 7$ countries will shape the policies that will be implemented by both developed and developing countries. 
$\mathrm{TDH}$, focused in this paper, is considered as a competing hypothesis of TA and REH. So, the theoretical framework of paper was derived from these hypotheses. This study contributes to empirical literature on the current account deficit and the budget deficit in two ways. Firstly, existing studies focus primarily on twin deficits, ignoring the effects of the savings-investment balance on the formation of the current account balance and budget balance. This study fills this gap. Secondly, empirical studies conducted on cases of twin deficits have used common classical approaches. ${ }^{1}$ This study uses an approach that takes into account cross-sectional dependence across the members of a panel. A panel data analysis usually controls for cross-sectional dependence across the members. Because the assumption of cross-sectional independence is difficult to satisfy in panel data, ignoring cross-sectional dependency causes bias and inconsistency (Bai and Kao, 2006). We believe that our study will contribute to the literature in this respect.

This study aims to determine the effects of savings on the current account deficit and the budget deficit by means of a panel data analysis, which allows us to account for crosssectional dependency. In the empirical analysis, the authors concentrate on G7 countries, in which savings rates are lower than those in devoloping countries.

The rest of paper is organized as follows. Section 2 summarizes the theoretical framework of the triplet deficit hypothesis. Section 3 covers the literature review about traditional approach, Ricardian equivalence hypothesis and triplet deficit. Section 4 describes the data and econometric methods used in the paper. Section 5 interprets the empirical results. Finally, Section 6 provides a brief summary and concluding remarks.

\section{Theoretical Framework}

With the liberalization of capital movements worldwide, the requirement that domestic investments should be limited to the amount of domestic savings has disappeared. When domestic investments are greater than domestic savings, the financing of the emergent savings-investment gap from abroad causes the savings-investment balance to play a role, along with the budget deficit, in the emergence of a current accounts deficit. This means that the budget balance, savings-investment balance, and current accounts balance of a country are all in deficit. Such a scenario is known as the triplet deficit hypothesis in the literature.

National income equations have historically represented the theoretical basis of the relationship between the budget deficit and the current account deficit (Lipsey et al., 1999). The theoretical basis of the relationship among the savings gap, the budget deficit, and the current account deficit can be obtained with Keynesian spending equation. It is as follows:

$$
Y=C+I+G+X-M=C+S^{P}+T
$$

where $Y$ is national income, $C$ is consumption expenditures, $I$ is investment expenditures, $G$ is public expenditures, $X$ is goods and services exports, $M$ is goods and services imports, $S^{P}$ is private savings, and $T$ is tax.

In outward oriented open economies total savings is equal to the addition of national savings and external savings.

1 The Ordinary Least Squares (OLS), Autoregressive Distributed Lag (ARDL), and Vector AutoRegressive (VAR) models and their common classical Granger causality tests were used in the studies. 


$$
S^{T}=S^{D}+S^{F}
$$

Where $S^{T}$ is total savings, $S^{D}$ is domestic savings and $\mathrm{S}^{\mathrm{F}}$ is foreign savings.

National savings are the addition of private sector and public savings in case of a closed economy. External savings are equal to X-M.

$$
S^{D}=S^{P}+S^{G}
$$

Where $S^{D}$ is domestic savings, $S^{P}$ is private savings and $S^{G}$ is government savings.

The definition of private and government savings are as follows:

$$
\begin{gathered}
S^{P}=Y-T-\mathrm{C} \\
\mathrm{S}^{\mathrm{G}}=\mathrm{T}-\mathrm{G}
\end{gathered}
$$

To sum up under the light of those data, to write the total savings again;

$$
S=(Y-T-C)+(T-G)+(X-M)
$$

With the help of these equations, the relationship among the budget deficit, the current account deficit, and the savings gap can be determined as follows:

$$
(X-M)=(S-I)+(T-G)
$$

When this equation is rearranged, we obtain the following notation:

$$
\text { Current Account Balance }=S^{D}
$$

According to the basic Keynesian model, this equation derived from the balance conditions of goods market in open economies shows that there is a relationship among Current Account Balance, Domestic Public Savings Balance and Public Budget Balance. As can be predicted, it is possible that these three macroeconomic balances result in deficit, surplus or balance.

Equation (7) establishes the theoretical basis of our study: the sum of the two balances, in which the right side of Equation (7) shows the internal balance of economics and the left side of Equation (7) determines the external balance of economics. Namely, the internal and external balances of economics are equal to each other, meaning that the more an internal balance has a deficit, the more the external balance has a deficit. In this context, an emerging savings gap, since domestic savings are smaller than domestic investments, causes a triple deficit (Szakolczai, 2006). In other words, if the private sector savings-investment balance or the public sector balance (which is on the right side of Equation (7) has a deficit and the current account balance accompanies this deficit, the twin deficit is valid in economics. If both of the internal economic balances have a deficit, the triple deficit is valid in economics. 


\section{Literature Review}

The studies in the literature discussing budget deficits and current deficit or handling the investment-saving deficit in addition to this twin deficit are summarized in Table 1. As it is seen in Table 1, twin deficit hypothesis has been the subject of numerous studies. These studies have tried to determine the direction of this relationship by using different methods for different countries or groups of countries. It is particularly seen that early studies focused on the US economy. However, similar studies also have been encountered for other countries. Studies focusing on twin deficits have obtained a variety of results. Prover findings to traditional opinion have been obtained in numerous studies. These studies have emphasized that budget deficits have a major impact on current account deficits. Some studies also obtained prover results for the REH which stated no interaction or restricted interaction between the two deficits (see Table 1).

Table 1 | Empirical Studies about Twin and Triplet Deficit Hypotheses

\begin{tabular}{|c|c|c|c|}
\hline Twin Deficit Studies & Country & Period & Results and findings \\
\hline Rafiq (2010) & $\begin{array}{l}\text { UK } \\
\text { US }\end{array}$ & $\begin{array}{l}1973-2008 \\
1973-2009\end{array}$ & $\begin{array}{l}\text { REH (for UK) } \\
\text { TA (for US) }\end{array}$ \\
\hline Zamanzadeh, Mehrara (2011) & Iran & 1959-2007 & TA \\
\hline Altıntaş, Taban (2011) & Turkey & 1974-2007 & TA \\
\hline Holmes (2011) & US & 1947-2009 & TA \\
\hline Ratha (2012) & India & 1998-2009 & $\begin{array}{l}\text { TA (short-run), REH } \\
\text { (long-run) }\end{array}$ \\
\hline Saeed, Khan (2012) & Pakistan & 1976-2010 & TA \\
\hline Kalou, Paleologou (2012) & Greece & 1960-2007 & TA \\
\hline $\begin{array}{l}\text { Sahoo, Das (2012) } \\
\text { Kalou, Suzanna (2012) }\end{array}$ & $\begin{array}{l}\text { India } \\
\text { Greece }\end{array}$ & $\begin{array}{r}1971-2010 \\
1960-2007 \\
\end{array}$ & $\begin{array}{l}\text { TA } \\
\text { TA }\end{array}$ \\
\hline Trachanas, Katrakilidis (2013) & $\begin{array}{l}\text { Portugal, Ireland, Italy, } \\
\text { Greece, Spain }\end{array}$ & 1971-2009 & TA \\
\hline Chihi, Normandin (2013) & $\begin{array}{l}24 \text { developing } \\
\text { countries }\end{array}$ & 1960-2005 & TA \\
\hline $\begin{array}{l}\text { Algieri (2013) } \\
\text { Constantine (2013) } \\
\text { Makin, Narayan (2013) }\end{array}$ & $\begin{array}{l}\text { Greece, Ireland, Italy, } \\
\text { Portugal, Spain } \\
\text { Eurozone countries } \\
\text { Australia }\end{array}$ & $\begin{array}{c}1980-2012 \\
2002-2008 \\
1983-2009\end{array}$ & $\begin{array}{l}\text { REH } \\
\text { TA } \\
\text { TA }\end{array}$ \\
\hline \multicolumn{4}{|l|}{ Triplet Deficit Studies } \\
\hline Tang (2014) & $A B D$ & 1960-2013 & TDH \\
\hline Sen et al. (2014) & Turkey & 1980-2010 & $\mathrm{TDH}$ \\
\hline Akbaş et al. (2014) & Turkey & 1960-2012 & $\mathrm{TDH}$ \\
\hline
\end{tabular}

Note: REH: Ricardian Equivalence Hypothesis, TA: Traditional (Keynesian) Approach, TDH: Triplet Deficit Hypothesis.

Source: authors' studies 
On the other hand, some studies have linked the principal cause of budget deficits to the savings gap and then they have found the deterioration of current account balance by extension this savings gap. In this respect, these studies have emphasized that both the traditional approach and the REH approach cannot be accepted directly and that the relationship between the budget deficit and current account deficit is complicated. Namely, these studies have found that the twin deficit hypothesis is doubtful and mainly reached conclusions which support the triple deficit hypothesis. However, studies which try to prove the triplet deficit hypothesis are mainly theoretical in nature (Cooper (2001), Mann (2002), Gale and Orszag (2003), Labonte (2005), Hubbard (2006), Szakolczai (2006), Elwell (2007, 2010), Feldstein (2008)). There are also empirical studies on triplet deficit hypothesis. These studies are presented in Table 1.

\section{Data and Methodology}

In this study, the validity of the triple deficit hypothesis in G7 countries was analysed. The analysis covers annual data for the period from 1994 to 2011. The original values are used in the econometric analysis. Moreover, the data are evaluated as a percentage of gross domestic product (GDP). The data and sources used in the study are presented in Table 2.

Table 2 | Data Set

\begin{tabular}{|l|l|l|}
\hline Data & Explanation & Sources \\
\hline $\boldsymbol{C A}$ & Current account deficit (\% of GDP) & Word Bank \\
\hline $\boldsymbol{B D}$ & Budget deficit (\% of GDP) & OECD \\
\hline SG & Savings gap (\% of GDP) & Word Bank \\
\hline
\end{tabular}

The $C A$ and $S G$ series were obtained from the electronic database of the World Development Indicator (WDI), a World Bank electronic database. The $B D$ series was also obtained from the Organisation for Economic Co-operation and Development (OECD) statistical database.

Firstly, cross-sectional dependence was analysed across the members of the panel. Then, the stationarity of the series were tested by panel unit root tests, which take crosssectional dependence into account. Afterwards, a panel co-integration analysis was carried out to determine whether there was a long-run relationship among the series. After the co-integration analysis, a co-integration vector estimator was applied to estimate the coefficients. Finally, a panel causality test was applied to determine whether there was a relationship among the series.

\subsection{Cross-Sectional Dependence}

Before considering panel analysis, it is best to examine the characteristics of cross-sectional dependency among countries. Cross-sectional dependency can be explained in terms of econometrics, as individuals forming the panels are related to error terms in the panel data model, which is given in Equation (9). In terms of economics, it could be exlained that in a situation in which the individuals forming the panel are effected by a shock, the other 
individuals of the panel will be effected as well (Akbaş et al., 2013).

$$
\begin{gathered}
y_{i t}=\alpha_{i}+\beta_{i} x_{i t}+\varepsilon_{i t} \\
\operatorname{Cov}\left(\varepsilon_{i t}, \varepsilon_{i j}\right) \neq 0
\end{gathered}
$$

There are different tests to analyse cross-section dependency in panel data. This paper uses tests developed by Breusch-Pagan (1980) $\mathrm{CD}_{\mathrm{LM} 1}$, Pesaran (2004) $\mathrm{CD}_{\mathrm{LM} 2}$, Pesaran (2004) $\mathrm{CD}_{\mathrm{LM}}$, and Pesaran et al. (2008) $\mathrm{CD}_{\mathrm{LM} 1 \text { adj }}$. The $\mathrm{CD}_{\mathrm{LM} 1}$ test, which was developed by BreuschPagan (1980), is calculated as below:

$$
C D_{L M 1}=T \sum_{i=1}^{N-1} \sum_{j=i-1}^{N} \hat{\rho}_{i j}^{2}
$$

This test is based on the sum of correlation coefficient squares among cross-section residuals, which are obtained from the OLS. $\mathrm{CD}_{\mathrm{LM} 1}$ test, which has $\mathrm{N}(\mathrm{N}-1) / 2$ degrees of freedom, is used when $\mathrm{N}$ is constant and $\mathrm{T} \rightarrow \infty$. This test investigates that no relations exist between cross sections under the null hypothesis and relations exist between cross sections under the alternative hypothesis.

The $\mathrm{CD}_{\mathrm{LM} 2}$ test, which is another test to examine cross-section dependency, is calculated as below.

$$
C D_{L M 2}=\sqrt{\frac{1}{N(N-1)}}\left[\sum_{i=1}^{N-1} \sum_{j=i+1}^{N} T \hat{\rho}_{i j}\right] \neq N(0,1)
$$

In this equation, $\hat{p}_{i j}^{2}$ shows the estimation of the sum of cross-section residuals. The test, which is used when $\mathrm{N}$ and $\mathrm{T}$ are great $(\mathrm{T} \rightarrow \infty$ and $\mathrm{N} \rightarrow \infty)$, has an asymptotically normal distribution.

The $\mathrm{CD}_{\mathrm{LM}}$ test, which is also another test to examine cross-section dependency, is calculated with the formula below.

$$
C D_{L M}=\sqrt{\frac{2 T}{N(N-1)}}\left[\sum_{i=1}^{N-1} \sum_{j=i+1}^{N} \hat{\rho}_{i j}\right] \neq N(0,1)
$$

$\mathrm{CD}_{\mathrm{LM}}$ test is based on the sum of correlation coefficient squares among cross-section residuals. This test, which has an asymptotically standard normal distribution, is used when $\mathrm{T}>\mathrm{N}$ and $\mathrm{N}>\mathrm{T}$. The null and alternative hypotheses for this test are similar to those of the $\mathrm{CD}_{\mathrm{LM} 1}$ and $\mathrm{CD}_{\mathrm{LM} 2}$ tests.

Lastly, the $\mathrm{CD}_{\mathrm{LM} 1}$ adj test is a modified version of the $\mathrm{CD}_{\mathrm{LM} 1}$ test, which was developed by Pesaran et al. (2008). This test is formulated as below.

$$
C D_{L M 1 a d j}=\frac{1}{C D_{L M 1}}\left[\frac{(T-k) \rho_{i j}^{2} \mu T_{i j}}{\sqrt{v_{i j}^{2}}}\right] \neq N(0,1)
$$

\subsection{CADF Unit Root Test}

The Covariate Augmented Dickey-Fuller (CADF) test is a test that considers cross-sectional dependence. This test can be used when $\mathrm{N}>\mathrm{T}$ and also gives strong results when $\mathrm{T}>\mathrm{N}$ (Akbaş et al., 2013, p. 797). In the CADF test developed by Pesaran (2007), the bootstrap method is not used to calculate critical values; instead, a Monte Carlo simulation is applied. 
Because of this, the critical values for the CADF test are obtained from the table values of Pesaran. The CADF test can be calculated as below:

$$
\Delta Y_{i t}=\alpha_{i}+b_{i} Y_{i, t-1}+\sum_{j=1}^{\rho i} c_{i j} \Delta Y_{i, t-j}+d_{i} t+h_{i} \bar{Y}_{t-1}+\sum_{j=0}^{\rho i} \eta \Delta \bar{Y}_{t-1}+\varepsilon_{i, t} \quad i=1,2, \ldots, t
$$

In this equation, $\alpha_{i}$ is constant, $\mathrm{t}$ is trend, $\Delta \bar{Y}_{t-1}$ is delays of differences and $\bar{Y}_{t-1}$ is the value of one term delay of ${ }^{-}$. The null and alternative hypotheses for CADF testing are as follows:

$$
\begin{aligned}
& H_{0}=\beta_{1}=\beta_{2}=\ldots \ldots \beta_{n}=0 \text { (series contains a unit root) } \\
& H_{A}=\beta_{1} \neq \beta_{2} \neq \ldots \ldots \beta_{n} \neq 0 \text { (series are stationary). }
\end{aligned}
$$

The CADF test cannot analyse the stationarity of all panels; thus, the CIPS test developed by Pesaran (2007) fills a gap of the CADF test. This test can analyse for all panels which series is stationary under the null hypothesis and use the Pesaran critical value.

\subsection{LM Bootstrap Panel Cointegration Test}

Lagrange Multiplier (LM) Bootstrap test developed by Westerlund and Edgerton (2007) can be used in both existence and non-existence of cross-sectional dependency. This test allows autocorrelation to differ from cross-section to cross-section. Moreover, it assumes the matrix of variance-covariance to be omega. In this test, the bootstrap method is used in the existence of cross-sectional dependency, and the McCoskey and Kao (1998) is used in the non-existence of it. This test analyses the co-integration under null hypothesis (Westerlund and Edgerton, 2007).

It is presumed that there is a panel data model as follows:

$$
\begin{gathered}
y_{i t}=\alpha_{i}+x_{i t}^{\prime} \beta_{i}+Z_{i t} \\
Z_{i t}=u_{i t}+v_{i t} \text { and } v_{i t}=\sum_{j=1}^{t} \eta_{i j} \\
w_{i t}=\sum_{j=0}^{\infty} \alpha_{i j} e_{i t-j}
\end{gathered}
$$

After expressing the model above, in a case of non-existence of cross-sectional dependency, a hypothesis test could be done using the LM test, as follow:

$$
L M_{N T^{2}}^{+}=\sum_{i=1}^{N} \sum_{t=1}^{T} \hat{\omega}_{i t}^{-2} S_{i t}
$$

where $S_{i t}$ is part of the $Z_{i t}$ process, which is a fully modified estimation of $Z_{i t}$, while $\hat{\omega}_{i t}^{2}$ is an estimation of long-term variance $\left(u_{i t}\right)$ LM test gives deviant results in a case of existence of cross-sectional dependency. Asymptotically standard normal distribution of LM test is also very sensitive to serial correlation. To overcome this problem, the bootstrap method is used instead of the asymptotically standard normal distribution (Westerlund and Edgerton, 2007).

The bootstrap method follows an autoregressive process, as below:

$$
\sum_{j=0}^{\infty} \phi_{i j} w_{i t-j}=e_{i t}
$$


The first stage in bootstrap scheme is to estimate $\phi_{i j}$ in Equation (18) using $\hat{w}_{i t}=\left(\hat{z}_{i t}, \Delta x_{i t}^{\prime}\right)^{\prime}$ instead of $w_{i t}$ and $\rho_{i}$ lags. Then, the residual can be computed as follows:

$$
\hat{e}_{i t}=\sum_{j=0}^{\infty} \hat{\phi}_{i j} w_{i t-j}
$$

At the second stage, $e_{t}^{*}$ is achieved from the empirical distribution of the residuals $\hat{e}_{t}-\frac{1}{T} \sum_{j=1}^{T} \hat{e}_{j}$. After that, instead of $\hat{w}_{i t}$ and $\hat{e}_{i t}$ in Equation (19), $e_{i t}^{*}$ and $w_{i t}^{*}$ are used in order to obtain $e_{t}^{*}$ and $w_{i t}^{*}$. At the last stage, $w_{i t}^{*}$ is separated as $w_{i t}^{*}=\left(z_{i t}^{*}, \Delta x_{i t}{ }^{\prime}\right)^{\prime}$, and the bootstrap samples $x_{i t}^{*}$ and $y_{i t}^{*}$ are formed following the process below.

$$
y_{i t}^{*}=\hat{\alpha}_{i}+x_{i t}^{*} \hat{\beta}_{i}+z_{i t}^{*} \text { and } x_{i t}^{*}=\sum_{j=1}^{1} \Delta x_{i j}^{*}
$$

\subsection{Dynamic Seemingly Unrelated Cointegrating Regressions}

Dynamic Seemingly Unrelated Regression (Dynamic SUR) estimators are proposed for small to moderate systems of $N$ equations of cointegrating regressions both in environments where the cointegrating vectors are homogeneous across equations and in environments where they exhibit heterogeneity. Estimation of the cointegration vector or vectors is straightforward, but inference is complicated because the regressors are typically endogenous in applications encountered in macroeconomic and international economic research. Properties of the dynamic SUR estimators can be made fully parametric and are computationally straightforward to use (Mark et al., 2005).

Dynamic SUR exploits the long-run cross-sectional dependence in equilibrium errors in estimation and is asymptotically efficient. Wald statistics with limiting chi-square distributions can be conveniently constructed to test cross-equation restrictions - such as homogeneity restrictions - on the cointegration vectors. Dynamic SUR estimator is an implentated in two-steps. In the first step, the regressand in each equation is regressed on the leads and lags of the first difference of the regressors from all equations to control for the endogeneity problem. In the second step, the SUR strategy is applied to the residuals from the first step regressions. Dynamic SUR is a parametric method for estimating multiple cointegrating regressions. It is feasible for balanced panels in which the number of cointegrating regression equations $(\mathrm{N})$ is substantially smaller than the number of time-series observations (T). The method is applicable both in environments where the cointegrating vectors are homogeneous across equations and in environments where they are not. Dynamic SUR estimators take endogenity into account, meaning that error terms are related to explanatory variables (Mark et al., 2005).

\section{Empirical Findings}

It is necessary to test cross-sectional dependence before starting the panel data analysis. Different panel data methods are used depending on the results of these tests which analyse the cross-sectional dependence. The results of the analysis for cross-sectional dependence are summarized in Table 3. 


\begin{tabular}{|l|c|c|c|c|c|c|c|c|}
\hline \multirow{2}{*}{ Variables } & \multicolumn{7}{|c|}{ Test } \\
\cline { 2 - 9 } & \multicolumn{2}{|c|}{$C D_{L M 1}$} & \multicolumn{2}{c|}{$C D_{L M 2}$} & \multicolumn{2}{c|}{$C D_{L M}$} & \multicolumn{2}{c|}{$C D_{{ }_{L M a d j 1}}$} \\
\cline { 2 - 9 } & statistic & $\boldsymbol{p}$-value & statistic & $\boldsymbol{p}$-value & statistic & $\boldsymbol{p}$-value & statistic & $\boldsymbol{p}$-value \\
\hline $\boldsymbol{C A}$ & 80.046 & 0.000 & 9.111 & 0.000 & -2.850 & 0.002 & 1.160 & 0.123 \\
\hline BD & 57.390 & 0.000 & 5.615 & 0.000 & -2.818 & 0.002 & 1.777 & 0.038 \\
\hline SG & 33.656 & 0.039 & 1.953 & 0.025 & -2.447 & 0.007 & 0.649 & 0.258 \\
\hline model & 59.317 & 0.000 & 5.912 & 0.000 & -0.273 & 0.393 & 8.166 & 0.000 \\
\hline
\end{tabular}

According to the results of the $\mathrm{CD}_{\mathrm{LM}}$ tests that analyse whether there is cross-sectional dependence in the units constituting the panel, the null hypothesis is rejected for all the variables and the model. Accordingly, there is a problem of cross-sectional dependence in the countries constituting the panel. Therefore, in each of the countries, the budget deficit and net saving gap affect the current deficit. In addition to this, the error term of each country is related to the error terms of the other countries. That is, the countries constituting the panel are highly correlated.

As there is a problem of cross-sectional dependence among the countries constituting the panel, methods that pay attention to this problem must be used in the panel data analysis. The CADF test is a panel unit-root test that takes cross-sectional dependencies into account. The results of the panel unit-root test analysis for the variables are shown in Tables 4 and Table 5.

Table 4 | The Results of CADF Panel Unit Root Test at Level

\begin{tabular}{|l|c|c|c|c|c|c|}
\hline \multirow{2}{*}{ Country } & \multicolumn{6}{|c|}{ Variables } \\
\cline { 2 - 8 } & \multicolumn{2}{|c|}{ CA } & \multicolumn{2}{c|}{ BD } & \multicolumn{2}{c|}{ SG } \\
\cline { 2 - 8 } Canada & -0.57 & 2.00 & -0.93 & 4.00 & -1.54 & 2.000 \\
\hline France & $-3.14^{*}$ & 4.00 & -2.46 & 2.00 & -2.08 & 2.000 \\
\hline Germany & -2.99 & 2.00 & -1.11 & 2.00 & -1.79 & 2.000 \\
\hline Italy & -0.98 & 2.00 & -1.81 & 2.00 & -0.62 & 4.000 \\
\hline Japan & -2.60 & 2.00 & 0.01 & 3.00 & -1.99 & 3.000 \\
\hline UK & -1.49 & 2.00 & -1.66 & 2.00 & $-3.31^{*}$ & 4.000 \\
\hline US & -0.24 & 2.00 & $-4.19^{* *}$ & 2.00 & $-4.44^{* *}$ & 2.000 \\
\hline CIPS-stat & \multicolumn{7}{|c|}{-1.71} & -1.738 & \multicolumn{2}{c}{-2.256} \\
\hline
\end{tabular}

Notes: ** and * stand for significance at 5 and $10 \%$ levels, respectively. The critical values for the SURADF test were generated using Monte Carlo simulations with 10, 000 replications.

The lag lengths $(p)$ are selected according to Schwarz information criterion.

The critical values for the CADF test were obtained from Pesaran (2007), Table I (b) Case II, for the CIPS test were obtained from Pesaran (2007), Table II(b) Case II. 
According to the results of the CADF test, the null hypothesis, which states that there is a unit root for the current deficit, is rejected for France. However, the null hypothesis cannot be rejected for the other six countries. Therefore, the current account deficit only includes a unit root in France, and it does not include a unit root in the other six countries.

The null hypothesis for budget deficit is rejected in the US, but it is not rejected in the other six countries. For this reason, the budget deficit includes a unit root only in the US. Finally, the null hypothesis stating that the net savings gap includes a unit root is rejected in the UK and the US. Accordingly, the net savings gap includes a unit root in the UK and the US. The results of the CIPS test revealing the panel statistics show that all three series have a unit root at the level.

After the unit-root test is conducted for the level values of the series, it is necessary to determine whether the differences among the series are stationary. In this context, the results of the unit-root test for the differences among the series are presented in Table 6.

Table 5 | The Results of CADF Panel Unit Root Test at First Difference

\begin{tabular}{|l|l|l|l|l|c|c|}
\hline \multirow{2}{*}{ Country } & \multicolumn{6}{c|}{ Variables } \\
\cline { 2 - 7 } & \multicolumn{2}{|c|}{ CA } & \multicolumn{2}{c|}{ BD } & \multicolumn{2}{c|}{ SG } \\
\cline { 2 - 7 } & CADF & $p$ & CADF & $p$ & CADF & $p$ \\
\hline Canada & $-3.66^{* *}$ & 2.00 & $-7.08^{* * *}$ & 4.00 & $-3.02^{*}$ & 2.00 \\
\hline France & $-3.02^{*}$ & 2.00 & $-3.06^{*}$ & 2.00 & -1.93 & 3.00 \\
\hline Germany & -1.67 & 2.00 & -1.03 & 3.00 & $-3.09^{*}$ & 2.00 \\
\hline Italy & $-3.22^{*}$ & 2.00 & $-4.69^{* * *}$ & 2.00 & -2.08 & 4.00 \\
\hline Japan & $-3.78^{* *}$ & 2.00 & $-4.75^{* * *}$ & 3.00 & -2.16 & 3.00 \\
\hline UK & $-6.21^{* * *}$ & 2.00 & -0.95 & 2.00 & $-3.05^{*}$ & 2.00 \\
\hline US & -1.66 & 2.00 & $-4.76^{* * *}$ & 2.00 & $-3.06^{*}$ & 2.00 \\
\hline CIPS-stat & \multicolumn{2}{|c|}{$-3.032^{*}$} & $-3.647^{* *}$ & \multicolumn{2}{c}{$-3.253^{*}$} \\
\hline
\end{tabular}

Notes: ${ }^{* * *}, * *$ and ${ }^{*}$ stand for significance at 1,5 and $10 \%$ levels, respectively. The critical values for the SURADF test were generated using Monte Carlo simulations with 10, 000 replications.

The lag lengths $(p)$ are selected according to Schwarz information criterion.

The critical values for the CADF test were obtained from Pesaran (2007), Table I (b) Case II, for the CIPS test were obtained from Pesaran (2007), Table II(b) Case II.

According to the results of the CADF test, which is conducted by taking the differences of the series, the null hypothesis stating that there is a unit root for the current deficit is rejected in Canada, France, Italy, Japan, the UK and the US. Therefore, in these countries, the current account deficit becomes stationary when the first difference is taken. For the budget deficit, the null hypothesis is not rejected in Germany or the UK, but it is rejected in the other five countries. Finally, for the net savings gap, the null hypothesis is rejected in four countries, but not in France, Italy or Japan. According to the results of the CIPS test, which is a panel statistics test, the null hypothesis is rejected for all three series. Thus, the current deficit, budget deficit and net savings gap series become stationary when the first difference is taken. The order of stationarity of these three series is $I(1)$. 
After testing the stationarity of the variables, the possible existence of a long-term relationship between the variables was analysed. The results of the LM Bootstrap test used for the analysis are presented in Table 6.

Table 6 | The Results of LM Bootstrap Panel Cointegration Test

\begin{tabular}{|c|c|c|}
\hline LM Statistic & Bootstrap $\boldsymbol{p}$-value & Asymptotic $\boldsymbol{p}$-value \\
\hline 3.318 & 0.893 & 0.251 \\
\hline
\end{tabular}

Note: The critical values for the LM Bootstrap test were generated using Monte Carlo simulations with 10,000 replications.

According to the results of the LM Bootstrap test, the null hypothesis that there is cointegration cannot be rejected for either the bootstrap or the asymptotic standard deviation. For this reason, it is concluded that there is a long-term relationship among the current deficit, the budget deficit and the net savings gap.

The fact that the variables are cointegrated enables us to estimate the coefficients of the model belonging to the triple deficit hypothesis. The results of the model estimated through the Dynamic SUR method are shown in Table 7.

Table 7 | The Results of Dynamic SUR Estimator

\begin{tabular}{|l|c|c|c|c|c|c|}
\hline \multirow{2}{*}{ Country } & \multicolumn{3}{|c}{ BD } & & \multicolumn{2}{c|}{ SG } \\
\hline & Coefficient & S.E & $t$-statistic & Coefficient & S.E & $t$-statistic \\
\hline Canada & 0.913 & 0.061 & $14.960^{* * *}$ & -0.232 & 0.211 & -1.099 \\
\hline France & 0.910 & 0.067 & $13.580^{* * *}$ & 0.749 & 0.090 & $8.322^{* * *}$ \\
\hline Germany & 1.402 & 0.029 & $48.340^{* * *}$ & 0.653 & 0.042 & $15.541^{* * *}$ \\
\hline Italy & 0.217 & 0.048 & $4.520^{* *}$ & 0.755 & 0.123 & $6.138^{* *}$ \\
\hline Japan & -0.325 & 0.046 & $-7.065^{* * *}$ & -0.175 & 0.092 & -1.902 \\
\hline UK & 1.040 & 0.071 & $14.647^{* * *}$ & -0.323 & 0.050 & $-6.460^{* * *}$ \\
\hline US & -0.016 & 0.017 & -0.941 & -1.666 & 0.040 & $-41.65^{* * *}$ \\
\hline PANEL & & $0.569^{* * *}$ & & $-0.034^{* * *}$ \\
\hline
\end{tabular}

Note: ${ }^{* *}$ and ${ }^{* *}$ stand for significance at 1 and $5 \%$ levels, respectively.

According to the results of the Dynamic SUR estimator, both the budget deficit and the net savings gap are statistically significant in the model. However, the budget deficit has a positive coefficient, whereas the net savings gap has a negative coefficient. According to this, an increase of $1 \%$ in the budget deficit increases the current deficit at a rate of $0.56 \%$. A $1 \%$ increase in net savings decreases the current deficit by $0.03 \%$. Based on these results, it can be said that the triple deficit hypothesis and traditional approach are valid in G7 countries.

When we assess the model separately for each country, it is seen that the budget deficit is statistically significant in six countries other than the US. The coefficient of the budget 
deficit series is negative in Japan and positive in the other five countries. These results imply that when the budget deficit increases, the current account deficit will decrease in Japan but increase in the other five countries. The net savings gap is statistically significant in the five countries other than Canada and Japan. This variable has a positive coefficient in France, Italy and Germany but a negative coefficient in the other two countries (UK and the US). These results signify that an increase in the net savings gap will cause an increase in the current deficit in France, Italy and Germany whereas an increase in net savings will decrease the current deficit in UK and the US. That is, the results of tests show that the triplet deficit hypothesis is valid in G7 countries. Moreover, traditional approach is also valid since the relationship was determined between the budget deficit and current deficit.

Considering Equation (7), the funding surplus that occurs in case the amount of savings is higher than investments is used either to meet the budget deficit or to make loans abroad. For this reason, a country that has a savings surplus is supposed to have a budget deficit or a current surplus. In cases where the amount of savings is smaller than the amount of investments, this funding gap is financed by either public savings or by borrowing from abroad. Therefore, a country that has a savings gap is supposed to have either a budget surplus or a current deficit. In addition to these, the difference of savings referred to as net capital outflow from investment is positive, the current account balance is also positive. If a country has a budget deficit in addition to a savings deficit, this increases the current deficit of the country concerned. Accordingly, when a country has a savings deficit, it needs to have a budget surplus in order not to have a current deficit. (Mankiw, 2009: pp. 121-123). If we canalize these events to Table 6 , the coefficients of savings deficit and budget deficit are required to be positive-signed. However, according to Table 6 , the savings deficit coefficient of the USA is negative. The level of welfare is quite high in the USA. For this reason, the consumption of the US citizens is high and their amount of savings is low. According to the World Bank Report (2012), the net savings ratio, budget deficit and current deficit of the USA are $-2.45 \%,-10.1 \%$ and $-2.9 \%$, respectively. The USA is a country that has savings deficit, and also budget deficit and current deficit. For this reason, budget deficit cannot be financed by budget surplus or current account surplus. This shows that investments are made in exporting sectors and the USA government implements tax incentives and tax concessions in order to support the exporters. Although the investments made in the exporting sectors have a negative effect on net savings, they increase exports and thus decrease current deficit. At the same time, although the application of policies such as tax reduction and tax incentive for the exporting sector increases budget deficit, such policies decrease current deficit since they have a positive effect on exports. The USA implemented a similar policy after the global economic crisis of 2008. In the USA, firstly, the Federal Reserve Bank implemented the quantitative easing policy in order to boost the economy. Afterwards, the US government covered the losses of various companies and implemented tax incentives for various sectors. As the result of these practices, expenditures increased and current deficit decreased. Therefore, the negative effect of savings deficit on current deficit in the USA can be explained in this way.

\section{Conclusion}

The level of welfare is high in G7 countries. In countries with high levels of welfare consumption, expenditures are also high, whereas savings are lower compared to consumption expenditures. Savings have a significant effect on both the budget balance and 
the current account balance. An inadequacy in savings has a negative effect on investments, which leads to a decrease in both the export revenues and the tax revenues to be taken from these investments. For this reason, the budget balance and the current account balance are negatively affected. Since savings have a significant effect on the budget deficit and the current deficit, policy makers need to give importance to policies that will increase saving rates. Although the US FED and the central banks of the other six G7 countries decreased interest rates to revive the markets after the crisis, in which occured $\mathrm{ABD}$ mortgage market and spread all of the contries in 2007. This study showed that many central banks could increase saving rates by increasing interest rates after the markets reach a certain level. Additionally, the liquidities transferred to the market can be decreased after the markets start to revive, and investments can be encouraged through stricter control of credits via new regulations on the banking sector. The public expenditures of G7 countries can be expected to fall back to normal levels with the gradual decrease of the effect of the global economic crisis. Moreover, the financial discipline that loosened as a result of the easing of taxes during the crisis can be regained with the revival of the markets. Thus, the budget deficit that started to increase because of the global economic crisis will decrease back to pre-crisis levels and stop being a threat for $\mathrm{G} 7$ countries.

What competent authorities need to do is to manage the crisis well. It can be said that the current deficit, the budget deficit and the net savings gap of $\mathrm{G} 7$ countries were at normal levels in the period before the crisis. These macroeconomic indicators can be expected to fall back to normal levels with the start of the recovery of the G7 countries' economies. So, the important thing is managing the crisis process well. The policy implementations of authorities may create a volatility and uncertanity such as increased public expenditure and current account deficit, political risk, volatility of interest rate. So, authorities should take into account the tendencies of global and domestic markets. In this regard, monetary policy and fiscal policy authorities should work in coordination. Monetary authorities aim at the price and financial stability. However, fiscal authorities are representatives of economic growth, employment and unemployment. If monetary policies implement the tight monetary policy for pressing the inflationary pressure, policies implemented by fiscal policy authorities may be unseccesful. Thereby, fiscal and monetary authorities should take into account the situations of global and domestic markets and business cycle before they implement the policies.

\section{References}

Akbaş, Y. E., Lebe, F., Zeren, F. (2014), "Testing the Validity of the Triplet Deficit Hypothesis for Turkey: Asymmetric Causality Analysis." Journal of Business and Economics, Vol. 7, pp. 137-154.

Akbaş, Y. E., Senturk, M., Sancar, C. (2013), "Testing for Causality between the Foreign Direct Investment, Current Account Deficit, GDP and Total Credit: Evidence from G7." Panoeconomicus, Vol. 60, No. 6, pp. 791-812, http://dx.doi.org/10.2298/PAN1306791A

Algieri, B. (2013), "An Empirical Analysis of the Nexus between External Balance and Government Budget Balance: The Case of the GIIPS Countries." Economic Systems, Vol. 37, No. 2, pp. 233-53, http://dx.doi.org/10.1016/j.ecosys.2012.11.002

Altıntaş, H., Taban, S. (2011), "Twin Deficit Problem and Feldstein-Horioka Hypothesis in Turkey: ARDL Bound Testing Approach and Investigation of Causality." International Research Journal of Finance and Economics, Vol. 74, pp. 30-45. 
Bai, J., Kao, C. (2006), "Chapter 1 On the Estimation and Inference of a Panel Cointegration Model with Cross-Sectional Dependence." Contributions to Economic Analysis, Vol. 274, pp. 3-30.

Barro, R. J. (1989), "The Ricardian Approach to Budget Deficits." The Journal of Economic Perspectives, Vol. 3, No. 2, pp. 37-54, http://dx.doi.org/10.1257/jep.3.2.37

Breusch, T., Pagan, A. (1980), "The Lagrange Multiplier Test and Its' Application to Model Specifications in Econometrics." Reviews of Economics Studies, Vol. 47, pp. 239-53.

Chihi, F., Normandin, M. (2013), "External and Budget Deficits in Some Developing Countries." Journal of International Money and Finance, Vol. 32, pp. 77-98, http://dx.doi.org/10.1016/j. jimonfin.2012.03.002

Constantine, C. (2014), "Rethinking the Twin Deficits." Munich Personal RePEc Archive.

Cooper, R. N. (2001), "Is the U.S. Current Account Deficit Sustainable? Will It Be Sustained?" Brookings Papers on Economic Activity, Vol. 1, No. 1, pp. 217-226, http://dx.doi.org/10.1353/eca.2001.0002

Elwell, C. K. (2007), “The U.S. Trade Deficit: Causes, Consequences and Cures.” CRS Report for Congress.

Elwell, C. K. (2010), “The U.S. Trade Deficit: Causes, Consequences and Policy Options.” CRS Report for Congress.

Feldstein, M. (2008), "Resolving the Global Imbalance: the Dollar and the U.S. Saving Rate." Journal of Economic Perspectives American Economic Association, Vol. 22, No. 3, pp. 113-25, http://dx.doi.org/10.1257/jep.22.3.113

Froyen, R. T. (1999), Macro Economics Theories and Policies, $6^{\text {th }}$ Ed. New Gesrey: Prentice Hall Inc.

Gale, W. G., Orszag, P. R. (2003), “Economic Effects of Sustained Budget Deficits.” National Tax Journal, Vol. 56, No. 3, pp. 463-485, http://dx.doi.org/10.17310/ntj.2003.3.02

Holmes, M. J. (2011), "Threshold Cointegration and the Short-Run Dynamics of Twin Deficit Behaviour." Research in Economics, Vol. 65, No. 3, pp. 271-277, http://dx.doi.org/10.1016/j.rie.2010.11.004

Hubbard, R. G. (2006), "The U.S. Current Account Deficit and Public Policy." Journal of Policy Modeling, Vol. 28, No. 6, pp. 665-71, http://dx.doi.org/10.1016/j.jpolmod.2006.06.006

Kalou, S., Suzanna, M. P. (2012), "The Twin Deficits Hypothesis: Revisiting an EMU Country." Journal of Policy Modeling, Vol. 34, No. 2, pp. 230-241, http://dx.doi.org/10.1016/j. jpolmod.2011.06.002

Khalid, A. M., Guan, T. W. (1999), “Causality Tests of Budget and Current Account Deficits: Cross-Country Comparisons." Empirical Economics, Vol. 24, No. 3, pp. 389-402, http://dx.doi.org/10.1007/s001810050062

Labonte, M. (2005), "Is the U.S. Trade Deficit Caused by a Global Saving Glut?" CRS Report for Congress.

Lipsey, R. G., Courant, P. N., Ragan, C. T. S. (1999), Economics, $11^{\text {th }}$ Ed. United States: The Addison-Wesley Publishing Company.

Makin, A., Narayan, P. (2013), "Re-examining the Twin Deficits Hypothesis: Evidence from Australia." Empirical Econonomics, Vol. 45, No. 2, pp. 817-829, http://dx.doi.org/10.1007/s00181-012-0628-7

Mankiw, N. G. (2009), Macroeconomics, 7th Ed. New York: Worth Publishers.

Mann, C. L. (2002), "Perspectives on the U.S. Current Account Deficit and Sustainability." Journal of Economic Perspectives, Vol. 16, No. 3, pp. 131-52, http://dx.doi.org/10.1257/089533002760278758 
Mark, N. C., Ogaki, M., Sul, D. (2005), “Dynamic Seemingly Unrelated Cointegrating Regressions." Review of Economic Studies, Vol. 72, No. 3, pp. 797-820, http://dx.doi.org/10.1111/j.1467-937X.2005.00352.x

Mccoskey, S., Kao, C. (1998), "A Residual-Based Test of the Null of Cointegration in Panel Data." Econometric Rewiews, Vol. 17, No. 1, pp. 57-84, http://dx.doi.org/10.1080/07474939808800403

Pesaran, H. M. (2004), "General Diagnostic Tests for Cross Section Dependence in Panels." Cambridge University, Working Paper No. 0435.

Pesaran, H. M. (2007), "A Simple Panel Unit Root Test in the Presence of Cross-Section Dependence." Journal of Applied Econometrics, Vol. 22, No. 2, pp. 265-312, http://dx.doi.org/10.1002/jae.951

Pesaran, H. M., Ullah, A., Yamagata, T. (2008), "A Bias-adjusted LM Test of Error CrossSection Independence." Econometrics Journal, Vol. 11, No. 1, pp. 105-27, http://dx.doi. org/10.1111/j.1368-423X.2007.00227.x

Rafid, S. (2012), "Fiscal Stance, the Current Account and the Real Exchange Rate: Some Empirical Estimates from a Time-Varying Framework." Structural Change and Economic Dynamics, Vol. 21, pp. 276-290

Ratha, A. (2012), "Twin Deficits or Distant Cousins? Evidence from India." South Asia Economic Journal, Vol. 13, pp. 51-68.

Saeed, S., Khan, M. A. (2012), "Ricardian Equivalence Hypothesis and Budgetary Deficits: The Case of Pakistan 1972-2008." Interdisciplinary Journal of Contemporary Research in Business, Vol. 3, pp. 1432-1446

Sahoo, D., Das, A. B. (2012), "ARDL Co-integration Approach to the External and Internal Sector Equilibrium of India." Procedia - Social and Behavioral Sciences, Vol. 62, pp. 812-816, http://dx.doi.org/10.1016/j.sbspro.2012.09.137

Sen, A., Senturk, M., Sancar, C., Akbas, Y. E. (2014), “Empirical Findings on Triplet Deficits Hypothesis: The Case of Turkey." Journal of Economic Cooperation and Development, Vol. 35, No. 1, pp. 81-102.

Szakolczai, G. (2006), "The Triple Deficit of Hungary." Hungarian Statistical Review, Vol. 84, pp. 40-62.

Tang, T. C. (2014), "Fiscal Deficit, Trade Deficit, and Financial Account Deficit: Triple Deficits Hypothesis with the U.S. Experience." Monash University Business and Economics Discussion Paper.

Trachanas, E., Katrakilidis, C. (2013), "The Dynamic Linkages of Fiscal and Current Account Deficits: New Evidence from Five highly Indebted European Countries Accounting for Regime Shifts and Asymmetries." Economic Modelling, Vol. 31, pp. 502-10, http://dx.doi.org/10.1016/j.econmod.2012.12.026

Vamvoukas, G. A. (1999), "The Twin Deficits Phenomenon: Evidence from Greece." Applied Economics, Vol. 31, No. 9, pp. 1093-1100.

Westerlund, J., Edgerton, D. L. (2007), "A Panel Boostrap Cointegration Test." Economic Letters, Vol. 97, pp. 185-190.

World Bank (2012), Global Economic Prospects Report. Washington DC: World Bank.

Zamanzadeh, A., Mehrara, M. (2011), "Testing Twin Deficits Hypothesis in Iran." Interdisciplinary Journal of Research in Business, Vol. 1, pp. 7-11. 